\title{
The effects of highly active antiretroviral therapy (HAART) of stavudine, lamivudine and nevirapine on the CD4 lymphocyte count of HIV-infected Africans: the Nigerian experience
} Osaro Erhabor*1, OA Ejele ${ }^{2}$ and CA Nwauche ${ }^{2}$ \author{
Teaching Hospital, P.M.B. 6173, Port Harcourt, Nigeria \\ * Corresponding author \\ from Frontiers of Retrovirology: Complex retroviruses, retroelements and their hosts \\ Montpellier, France. 21-23 September 2009 \\ Published: 24 September 2009 \\ Retrovirology 2009, 6(Suppl 2):P66 doi:10.1 I86/1742-4690-6-S2-P66
}

Address: ${ }^{1}$ Blood Sciences Department Royal Bolton Hospital NHS Trust Bolton UK and ${ }^{2}$ Department of Haematology University of Port Harcourt

This abstract is available from: http://www.retrovirology.com/content/6/S2/P66

(c) 2009 Erhabor et al; licensee BioMed Central Ltd.

\section{Objectives}

The objective of this study was to investigate the shortterm effect of highly active antiretroviral therapy on the CD4 lymphocyte count of HIV-infected Nigerians.

\section{Setting}

This study was carried out at the Haematology Department of the University of Port Harcourt Teaching Hospital a 500 bed tertiary hospital and one of the designated antiretroviral therapy pilot centres.

\section{Methods}

A case control study of $70 \mathrm{HIV}$-infected subjects placed on highly active antiretroviral therapy. Thirty HIV-infected yet to start therapy due to unaffordability were observed as controls. CD4 lymphocyte count was determined at baseline for subjects and controls. Subjects were placed on HAART for 12 weeks while controls that were yet to start therapy were monitored as controls. CD4 lymphocyte count was repeated after 12 weeks and the differences compared statistically.

\section{Results}

We observed that subjects and control patients did not differ significantly in their CD4 lymphocyte count at baseline ( $\mathrm{p}>0.05)$, but after 12 weeks HAART in subjects, there was a mean increase in CD4 count of (39 cells/ $\mu$ l) in subjects, while untreated controls showed a mean decline of $(12$ cells $/ \mu \mathrm{l}) \mathrm{p}<0.05$. There was a statistically signifi- cant variation in the therapy dependent increases in CD4 count of HAART treated subjects based on pre-therapeutic baseline CD 4 count $\left(\chi^{2}=180.39, \mathrm{p}<0.05\right)$. The HAART dependent increase in CD4 counts was higher in younger subjects $19-28$ years $(31$ cells/ $\mu \mathrm{l}$ ) compared to older subjects $49-58$ years $(21$ cells $/ \mu \mathrm{l})(\mathrm{p}=0.01)$. Similarly CD4 response was found higher in females compared to males $(\mathrm{p}=0.01)$.

\section{Conclusion}

This study indicates the importance of accessing the CD4 lymphocyte count of HIV infected patients before the initiation of HAART, its use as a prognostic maker in predicting the initial response to HAART and in determining the optimal time to initiate therapy. 